\title{
Quadratic Mathematical Modeling of Sustainable Dry Beneficiation of Kaolin
}

\author{
Muhammad Badar Hayat ${ }^{1}$ (D), Muhammad Danishwar ${ }^{2}$, Amna Hamid $^{1}$, Mirza Muhammad Zaid ${ }^{1}$ \\ and Muhammad Zaka Emad 1,*(D)
}

1 Department of Mining Engineering, University of Engineering and Technology, Lahore 54890, Pakistan; badar@uet.edu.pk (M.B.H.); amnahamid258@yahoo.com (A.H.); mirzamuhammadzaid@uet.edu.pk (M.M.Z.)

2 Department of Mining and Geological Engineering, The University of Arizona, Tucson, AZ 85721, USA; danishwar@email.arizona.edu

* Correspondence: muhammad.emad@mail.mcgill.ca; Tel.: +92-333-463-4361

check for updates

Citation: Hayat, M.B.; Danishwar, M.; Hamid, A.; Zaid, M.M.; Emad, M.Z. Quadratic Mathematical Modeling of Sustainable Dry Beneficiation of Kaolin. Minerals 2021, 11, 429. https://doi.org/10.3390/ $\min 11040429$

Academic Editor: Chiharu Tokoro

Received: 3 March 2021

Accepted: 14 April 2021

Published: 18 April 2021

Publisher's Note: MDPI stays neutral with regard to jurisdictional claims in published maps and institutional affiliations.

Copyright: (c) 2021 by the authors. Licensee MDPI, Basel, Switzerland. This article is an open access article distributed under the terms and conditions of the Creative Commons Attribution (CC BY) license (https:// creativecommons.org/licenses/by/ $4.0 /)$.

\begin{abstract}
Clay minerals are one of the most utilized minerals among non-metals. These are hydrous aluminum silicates with a layer (sheet-like) structure. Kaolin is a hydrous aluminosilicate mineral with a thin platelet structure. Kaolin is extensively used in paper, paint, and many other industries. Wet processing of kaolin will not be sustainable over the long term because global freshwater resources are becoming scarce. Hence, a process is necessary that does not consume water during the beneficiation of kaolin. This study developed a dry beneficiation process for low-grade kaolin of $59.6 \%$, with $12 \%$ quartz and about $6 \%$ titaniferous impurities from Nagar Parkar, Sindh province, Pakistan. To develop a size difference between kaolinite and impurities, steel balls clad with rubber were used as the grinding media in a selective grinding unit. Screens of 60 and 400 mesh were employed to classify the feed of air classifier. Oversize +60 mesh was reground, 400 to 60 mesh fractions were sent to an air classifier, and -400 mesh was considered to be a product with the grade and recovery of $90.6 \%$ and $20.5 \%$, respectively. Air classifier experiments were designed using central composite design. An experiment using a fan speed of 1200 revolutions per minute (rpm) and a shutter opening of 4.0 showed optimum results, with maximum kaolinite grade and recovery of $91.5 \%$ and $35.9 \%$, respectively. The statistical models developed for grade and recovery predicted the optimum results at a fan speed of $1251 \mathrm{rpm}$ and shutter opening of 3.3 with the maximum kaolinite grade and recovery of $91.1 \%$ and $24.7 \%$, respectively. The differences between experimental and predicted grade and recovery were $0.1 \%$ and $2.4 \%$, respectively. The characterization results showed the total upgrade of kaolin from $59.6 \%$ to $91.2 \%$, with $27.1 \%$ recovery during the process. The designed methodology has the potential to improve the yield of the product by focusing on its recovery. Furthermore, the designed process can be improved by using different sized balls in the selective grinding unit. This beneficiation process can utilize more than one air classifier in series to achieve the targeted results.
\end{abstract}

Keywords: beneficiation; kaolin; dry process; attrition; differential grinding; air classification

\section{Introduction}

The name "kaolin" is derived from the Chinese term "Kauling", meaning high ridge. This is the name of a hill near Jauchau Fu, China, where this material was first mined centuries ago for ceramics [1]. The main constituent of kaolin is kaolinite, which is a hydrous aluminum silicate with an approximate composition of $2 \mathrm{H}_{2} \mathrm{O}-\mathrm{A}_{2} \mathrm{O}_{3}-2 \mathrm{SiO}_{2}$ [2] Crude kaolin contains various discoloring elements, such as anatase $\left(\mathrm{TiO}_{2}\right)$, mica, and iron oxide $\left(\mathrm{Fe}_{2} \mathrm{O}_{3}\right)$, which results in low brightness $[3,4]$. Kaolin is extensively used in paper, paint, and many other industries.

Wet and dry methods are employed to beneficiate crude kaolin to meet the requirements of different industries such as fiberglass and ceramics. [5]. Wet methods consist 
of both physical and chemical processes. Major wet physical processes constitute sedimentation [6] and electromagnetic separation $[7,8]$. Important wet chemical processes include selective flocculation $[3,9,10]$, flotation [11,12] and microbial purification [13]. Wet processing of kaolin can achieve the brightness grade of $80 \%$ to $90 \%$ required by the paper industry, $80 \%$ to $85 \%$ for the filler industry, $85 \%$ to $90 \%$ for the coating industry $[5,14]$ and potentially $94 \%$ for high-specification kaolin products [15]. Flotation has the highest potential to achieve a $90 \%$ brightness grade [5]. High gradient magnetic separation can produce kaolin grade from $80 \%$ to $90 \%[5,16]$. Bioleaching of iron from kaolin can produce product with a $60 \%$ whiteness grade [17] and an $80 \%$ brightness grade [18].

Dry methods constitute air classifying and air flotation techniques [19]. Air classifiers are usually employed in an open or closed circuit with a grinding mill $[20,21]$. Dry processing of kaolin is water conserving, but has relatively lower efficiency and results in a lower quality product than wet processing $[19,22]$.

Although wet methods are more effective than dry ones, wet methods do not support Goal 6 (Clean Water and Sanitation), Goal 9 (Industries, Innovation, and Infrastructure), and Goal 12 (Responsible Consumption and Production) of the United Nation's Sustainable Development Goals (SDGs), which were developed to promote prosperity while protecting the environment. Moreover, the use of wet processing either requires introduction of tailing dams or the use of 'unfriendly' chemicals for dense media separations that have considerable impact on handling and disposal. Wet processing also increases operating costs due to plant instability, material handling, thickening, filtration, and product drying. To meet the mentioned SDGs and to avoid problems related to wet processing, it is required to make improvements to the way water is utilized and managed in wet processing [23]. One way to achieve this is to use sea water in wet processing instead of fresh water. However, the use of sea water in the wet beneficiation process is not recommended due to its adverse effects on the processes' efficiency [24,25]. Sea water increases the complexity of the process because of additional unwanted ions in the water [26]. Water recycling in wet processing is another approach to save fresh water resources, however it also complicates the process and the resulting tailings have a diversity of ions and compounds, which can have deleterious effects on the environment $[27,28]$.

Wet methods, therefore, need to be replaced by dry approaches. Extensive work is required on the design of innovative dry processing to make it feasible for relevant industries towards a sustainable future. Few studies have been published with respect to dry processing of kaolin during the past decade, and almost no studies have been published to date on dry processing of kaolin originating from south Asia.

Furthermore, traditional dry separators, such as fine screens, rotary vane classifiers, or air cyclones, cannot be used for moist materials ( $>2$ per cent), have low unit throughput, produce a fixed cut size, and are therefore impractical where very high unit capacity and low operating costs are required.

The aim of this research was to contribute towards replacement of wet processing of kaolin with dry processing, and to examine if dry processing can accomplish the grade and recovery required by different industrial applications. This research is also aimed at addressing the capacity and operating cost issues related to conventional dry processing. For this purpose, mathematical modeling of the air classifier operation was carried out to understand the effect of different operating variables on the performance of the air classifier. This study will also enhance the limited amount of published data on dry processing of kaolin. An innovative selective grinding unit was used to ensure the size difference between kaolinite and impurities. This study will provide valuable information for ensuring the sustainable future of kaolin processing, particularly in countries such as China, Germany, and USA, which are facing water scarcity and are large exporters of kaolin [29]. 


\section{Geology of Deposit}

The Nagar Pakrkar area lies in the Thar Parkar district of the Sindh province of Pakistan, $\sim 400 \mathrm{~km}$ south east of Karachi at $24^{\circ} 15^{\prime}$ to $24^{\circ} 30^{\prime} \mathrm{N}, 70^{\circ} 37^{\prime}$ to $71^{\circ} 07^{\prime} \mathrm{E}$ [30]. Figure 1 demonstrates the location of Nagar Parker on a map of Pakistan. Nagar Parkar is the only other area in Pakistan, in addition to the Kirana hills in Punjab, characterized by Precambrian outcrops of the Indian Shield. The stratigraphic successions of Nagar Parkar are presented in Table 1 [31].

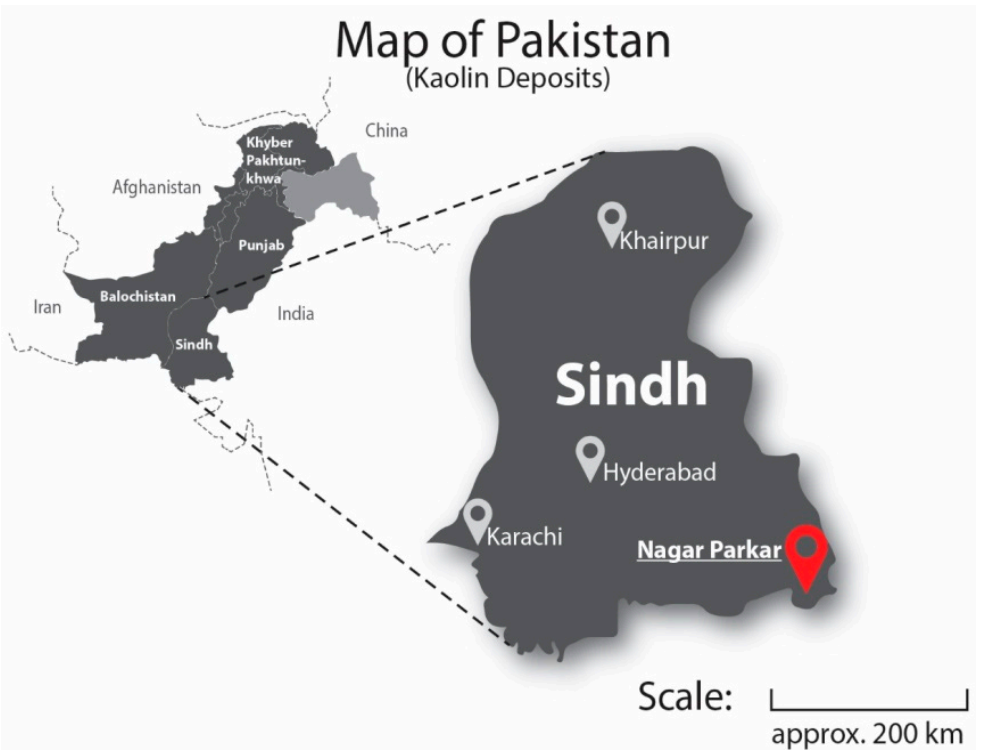

Figure 1. Location of Nagar Parkar is indicated by the red pin point on the map of Sindh province of Pakistan.

Table 1. General stratigraphic succession in Nagar Parkar area.

\begin{tabular}{|c|c|c|}
\hline Age & Group & Rock/Deposits \\
\hline Early Recent to Recent & Unconsolidated Quaternary Deposits & $\begin{array}{l}\text { Stream sandstone and food pain de-posits, Playa } \\
\text { and evaporate deposit. } \\
\text { Outwash deposits, piedmont, and } \\
\text { sub-piedmont deposits }\end{array}$ \\
\hline \multicolumn{3}{|c|}{ Unconformity } \\
\hline Cretaceous to Eocene & Sedimentary Rocks & $\begin{array}{c}\text { Acolian sand deposits, Rann of Kutch mud deposits } \\
\text { Residual deposits; Laterite/Kaolin Bartala } \\
\text { Sedimentary unit }\end{array}$ \\
\hline \multicolumn{3}{|c|}{ Unconformity } \\
\hline Precambrian & Nagar Parkar Igneous Complex & $\begin{array}{c}\text { Basement (metabasites) with acidic basic dykes and } \\
\text { pink/grey granite }\end{array}$ \\
\hline
\end{tabular}

\section{Materials and Methods}

\subsection{Materials}

Kaolin samples used in this experimental study were collected from Nagar Parkar, Sindh Province of Pakistan. The average specific gravity of kaolin samples was 2.57 [31] with average moisture content of $7.19 \%$. The size analysis of feed was carried out using the sieves of "TYLER" series. Standard sieves of 3, 5, 10, 16, 20, 30, 50, 70, 120, 200, 230,325 mesh with a diameter of 8 inches were used mounted on a Ro-Tap sieve shaker. (SEM) Scanning Electron Microscope (P TESCAN Vega LMU-Variable pressure) was used to acquire microscopic images of the samples. Samples were also characterized by X-ray diffraction (XRD) using Philips PANalytical X'Pert Powder to determine the relative 
percentage of different crystals. XRD data points were taken from a range of angle of $5^{\circ}$ to $70^{\circ}$. Samples for X-ray fluorescence (XRF) analysis were sent to Geoscience Advance Research Laboratories, Islamabad, Pakistan.

Processing of kaolin was carried out in Mineral Processing Lab I and II of Department of Mining Engineering at University of Engineering and Technology, Lahore, Pakistan. The process required a Denver Blake Jaw Crusher with the crushing capacity of $600 \mathrm{lb} / \mathrm{h}$, a Denver Roll Crusher (FOOTE BROS 212A-213) of capacity 2 ton/hour, and an indigenously manufactured selective grinding unit of $226.19 \mathrm{in}^{3}$ volumes with rubber-clad steel balls. Each ball had a diameter of $2.67 \mathrm{~cm}$. A circulating type of air classifier (model: KINCSTON98) was used for separating kaolinite and impurities.

\subsection{Procedure}

The processing procedure for kaolin designed in this study is presented in Figure 2. A representative sample was crushed by a jaw crusher followed by a roll crusher. The set for the jaw crusher was kept at $3 \mathrm{~mm}$ and that of the roll crusher at $1 \mathrm{~mm}$. The moisture content of the crushed product was determined using ASTM DD2216-19. The dried crushed product was then fed into the selective grinding unit, which was a modified stainless cylindrical steel container. Table 2 shows the range of values used in this study for the operating variables of the selective grinding unit [32-34].

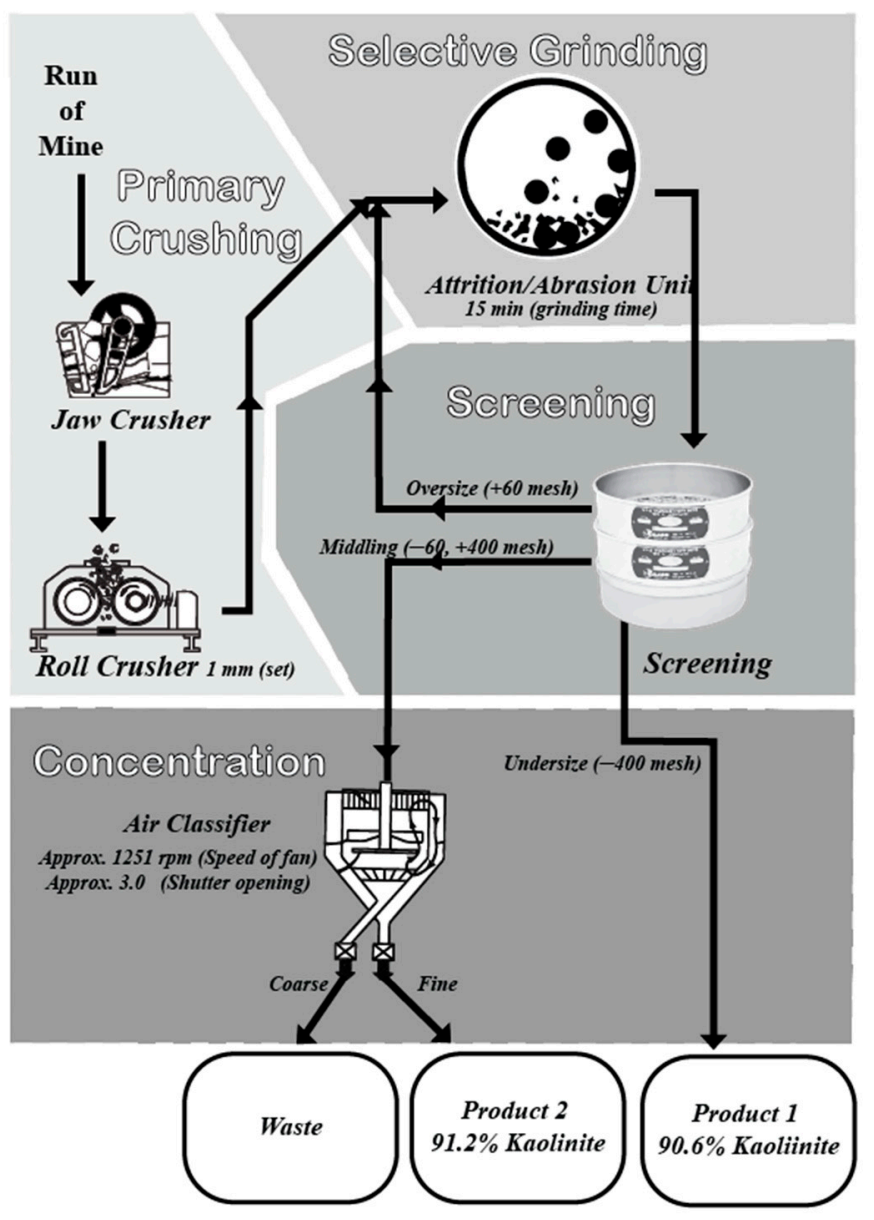

Figure 2. The process flow sheet for dry processing of kaolin designed and followed for this study. 
Table 2. Ranges of operating variables of selective grinding unit; selected based on previous studies.

\begin{tabular}{cc}
\hline Operating Variables & Operating Values \\
\hline Nature of balls & Rubber balls with iron core \\
Resident Time & $5,10,15,20,25$ and $30 \mathrm{~min}$ \\
Ball Volume Percentage & $40 \%$ \\
\hline
\end{tabular}

After selective grinding, representative samples were taken for XRD and XRF analysis. Screens of 60 and 400 mesh were used to screen out the +60 mesh and -400 mesh fraction. The undersize $(-400$ mesh) fraction was taken as the product. The oversize (+60 mesh) fraction was reground in the selective grinding unit. The medium $(-60,+400$ mesh $)$ fraction was fed into the air classifier because this size was consistent with the effective working size range of the air classifier. The experiments for the air classifier were designed via Minitab ${ }^{\circledR}$ version 17.3.1 using central composite design; Table 3 shows the operating variables and ranges for the air classifier considered during this study [35-37]. The fine fraction of air classifier was taken as concentrate and the coarse fraction was considered to be tailing. The detailed methodology is provided in the thesis [38].

Table 3. Minitab-designed experiments using central composite design for the air classifier.

\begin{tabular}{cccccc}
\hline StdOrder & RunOrder & PtType & Blocks & Speed of Fan (rpm) & Shutter Opening \\
\hline 5 & 1 & -1 & 1 & 234.3 & 2.5 \\
9 & 2 & 0 & 1 & 800.0 & 2.5 \\
10 & 3 & 0 & 1 & 800.0 & 2.5 \\
12 & 4 & 0 & 1 & 800.0 & 2.5 \\
3 & 5 & 1 & 1 & 400.0 & 4.0 \\
1 & 6 & 1 & 1 & 400.0 & 1.0 \\
6 & 7 & -1 & 1 & 1365.7 & 2.5 \\
7 & 8 & -1 & 1 & 800.0 & 0.4 \\
2 & 9 & 1 & 1 & 1200.0 & 1.0 \\
4 & 10 & 1 & 1 & 1200.0 & 4.0 \\
8 & 11 & -1 & 1 & 800.0 & 4.6 \\
13 & 12 & 0 & 1 & 800.0 & 2.5 \\
11 & 13 & 0 & 1 & 800.0 & 2.5 \\
\hline
\end{tabular}

\section{Results and Discussion}

\subsection{Feed Characterization}

SEM images for raw kaolin feed are shown in Figures 3 and 4. These images confirm the hexagonal flaky structure of kaolinite. The other particles of irregular shape were considered to be impurities. The XRD test of the feed showed the proportion of kaolinite in the kaolin sample was 59.6\%. Quartz and titaniferous fractions were the major impurities, comprising $12 \%$ and $6 \%$ of the sample respectively (Table 4 ). The XRF results of the feed indicated that the amount of $\mathrm{Al}_{2} \mathrm{O}_{3}$ was $34.23 \%$ in the sample (Table 5). After passing through the roll crusher, this feed was subjected to sieve analysis.

Table 4. Results of XRD analysis of kaolin feed showing the compounds with their average percentages.

\begin{tabular}{cc}
\hline Compounds & Avg. Percentage \\
\hline $\mathrm{Kaolinite}$ & 59.6 \\
$\mathrm{SiO}_{2}$ & 12.0 \\
$\mathrm{TiO}_{2}$ & 1.2 \\
$\mathrm{Fe}_{2} \mathrm{O}_{3}$ & 4.8 \\
$\mathrm{MgCO}_{3}$ & 4.8 \\
$\mathrm{CaCO}_{3}$ & 8.3 \\
$\mathrm{CaO}$ & 0.8 \\
$\mathrm{MgO}$ & 3.4 \\
$\mathrm{MnO}_{2}$ & 5.1 \\
\hline
\end{tabular}




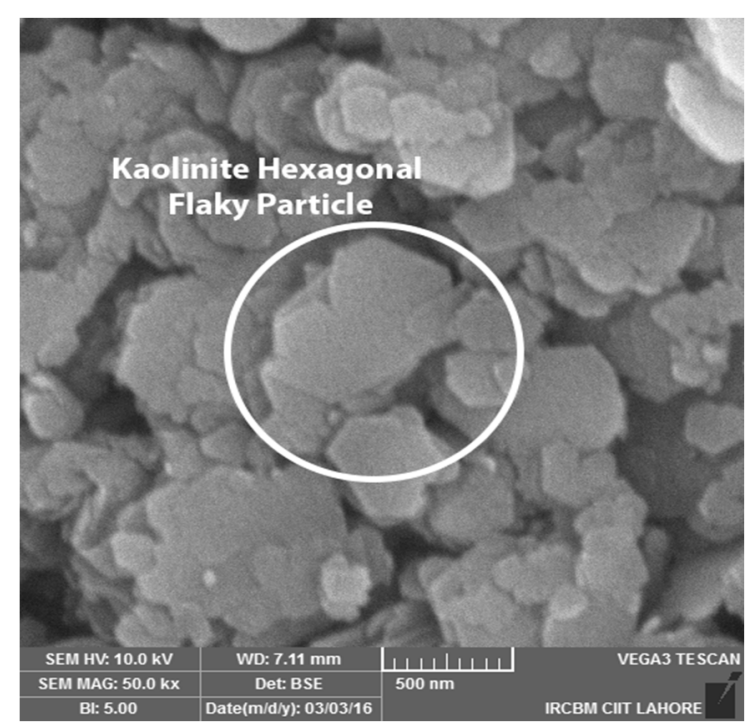

Figure 3. SEM image of kaolin feed magnified 25 times.

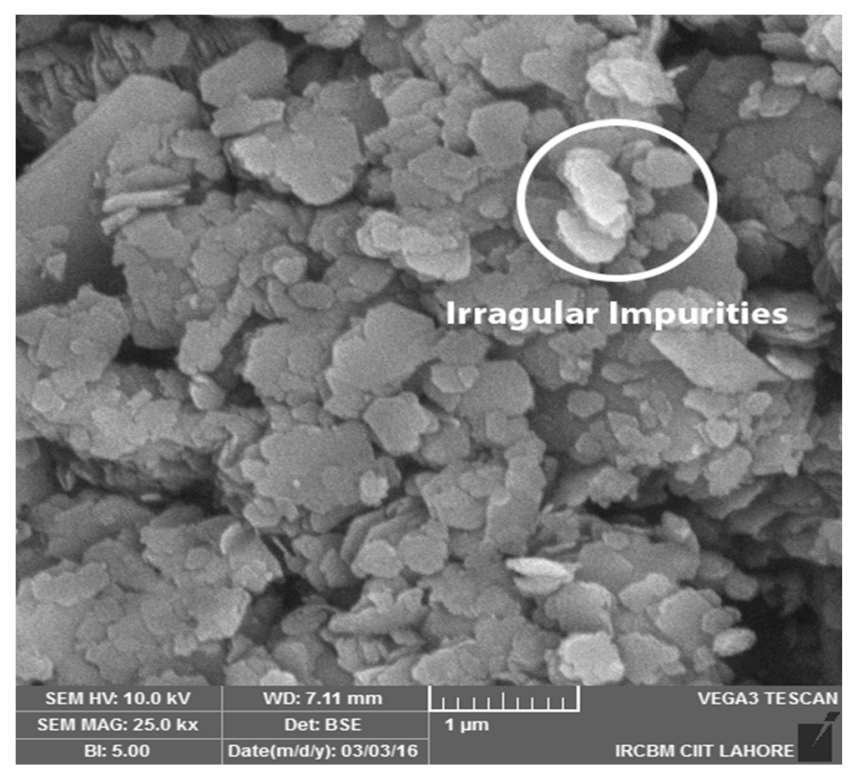

Figure 4. SEM image of kaolin feed magnified 50 times.

Table 5. XRF result of raw kaolin feed showing the highest percentage of $\mathrm{SiO}_{2}$. The $\mathrm{MgO}$ and $\mathrm{Na}_{2} \mathrm{O}$ percentages were less than the detection limit of instrument used.

\begin{tabular}{cc}
\hline Elements & Wt. Percentage \\
\hline $\mathrm{SiO}_{2}$ & 52.90 \\
$\mathrm{TiO}_{2}$ & 1.69 \\
$\mathrm{Al}_{2} \mathrm{O}_{3}$ & 34.23 \\
$\mathrm{Fe}_{2} \mathrm{O}_{3}$ & 0.91 \\
$\mathrm{MgO}$ & - \\
$\mathrm{CaO}$ & 0.24 \\
$\mathrm{Na}_{2} \mathrm{O}$ & - \\
$\mathrm{K}_{2} \mathrm{O}$ & 0.20 \\
$\mathrm{P}_{2} \mathrm{O}_{5}$ & 0.16 \\
$\mathrm{LOI}$ & 9.68 \\
\hline
\end{tabular}

The Rosin-Rammler distribution plot of the roll crusher product obtained from sieve analysis is shown in Figure 5. The values of its size and distribution parameters calculated 
from the model were found to be -1.28 and 14.68 , respectively. The value of the distribution parameter $(-1.28)$, indicates that there was a wide range of differently sized particles in the sample. After crushing using the roll crusher, the product was fed into the selective grinding unit for further size reduction.

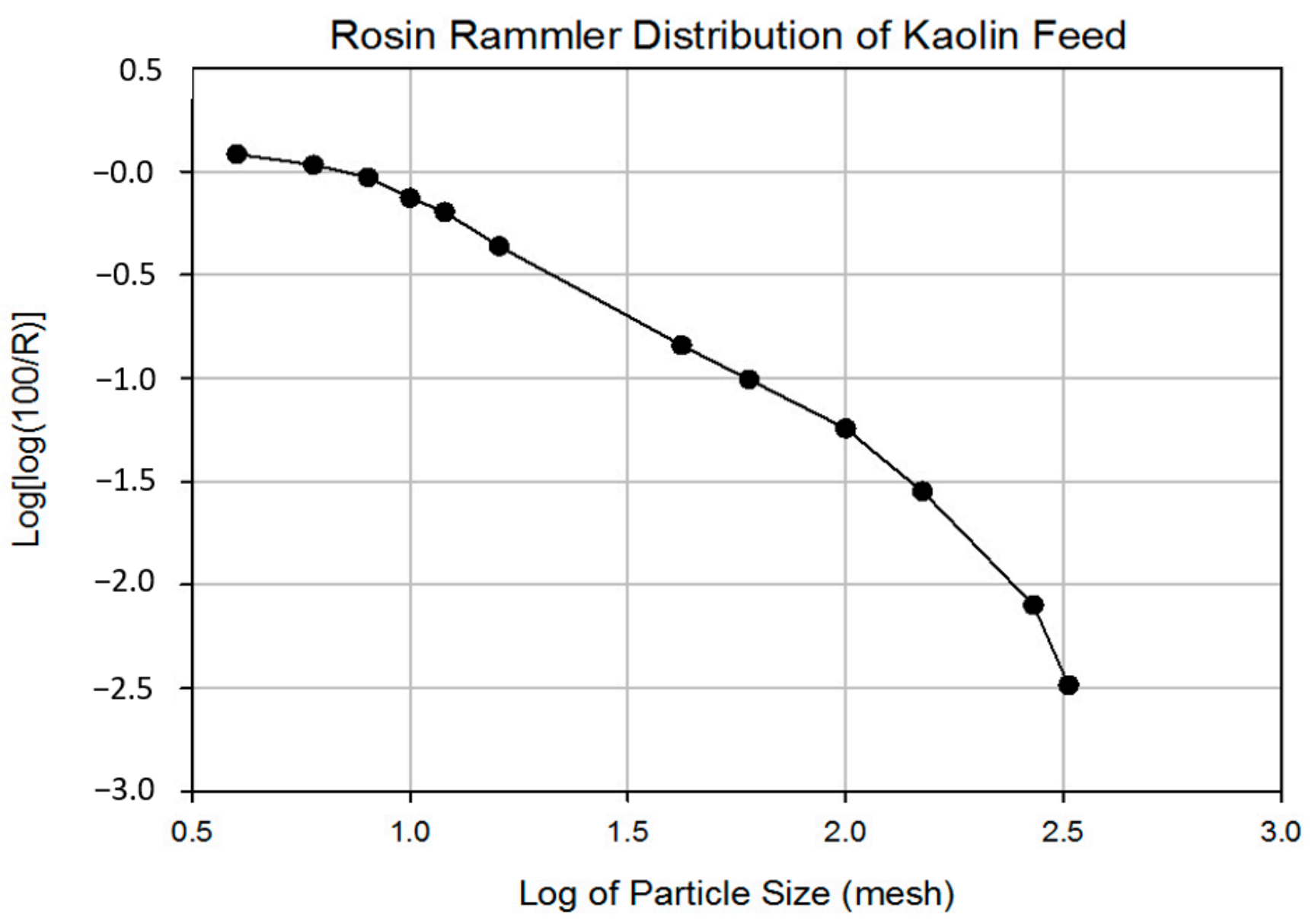

Figure 5. Rosin-Rammler distribution of roll crusher product.

A special type of selective grinding unit was employed for further processing of the roll crusher product. This selective grinding unit was indigenously manufactured. From literature analysis, it was observed that in the case of minerals with different values of Mohs hardness, such as limestone with 4.0 and olivine sand with 7.0, low shear grinding exhibits selective grinding towards minerals of lower hardness [39,40]. The kaolin ore in this study contained quartz and kaolinite, which have a considerable hardness difference. The hardness value of kaolin is 2.5 (i.e., soft to touch) [41], whereas for quartz it is 7.0 [42]. Based on this information, a hypothesis was proposed that by using rubber-clad steel balls for grinding, kaolinite would be ground in preference to the quartz impurities.

A total of five grinding experiments using selective grinding unit were therefore designed and executed for different times of 5, 10, 15, 25, and $30 \mathrm{~min}$ to test the hypothesis. A sieve set of 200, 230, and 270 mesh was used for size analysis of different grinding experiments. After sieving, four fractions were obtained for each of the grinding times. Fractions of 10, 15, and 25 min grinding time were sent for XRD analysis, excluding both of the extremes of 5 and 30 min grinding time. The graph in Figure 6 plots the fractions on the $\mathrm{x}$-axis (e.g., AA-15, +270 represents the 15 min grinding time and fraction of +270 mesh), and their grade and recovery on the $y$-axis.

A maximum kaolinite grade of $89 \%$ with recovery of $23 \%$ was achieved at a -270 mesh fraction after grinding for $15 \mathrm{~min}$. For the same grinding time, only $34 \%$ grade was achieved with recovery of $44 \%$ using the +200 mesh fraction. The hypothesis that kaolinite would 
be ground more than quartz in the feed using rubber-clad balls is proved by the data presented in the Figure 6. It was found that the $15 \mathrm{~min}$ (fraction AA-15-270) grinding time resulted in the greatest differential grinding for kaolin rock. The XRF results of fraction AA-15 -270 are listed in Table 6. Based on these results, the entire roll crusher product was ground for $15 \mathrm{~min}$ in the selective grinding unit. The granulometric analysis of the product after 15 min of grinding time revealed an 80 percent passing size of 56 micron (Figure 7). The ground kaolin from the selective grinding unit was then fed into a set of screens with mesh sizes of 60 and 400 for further classification.

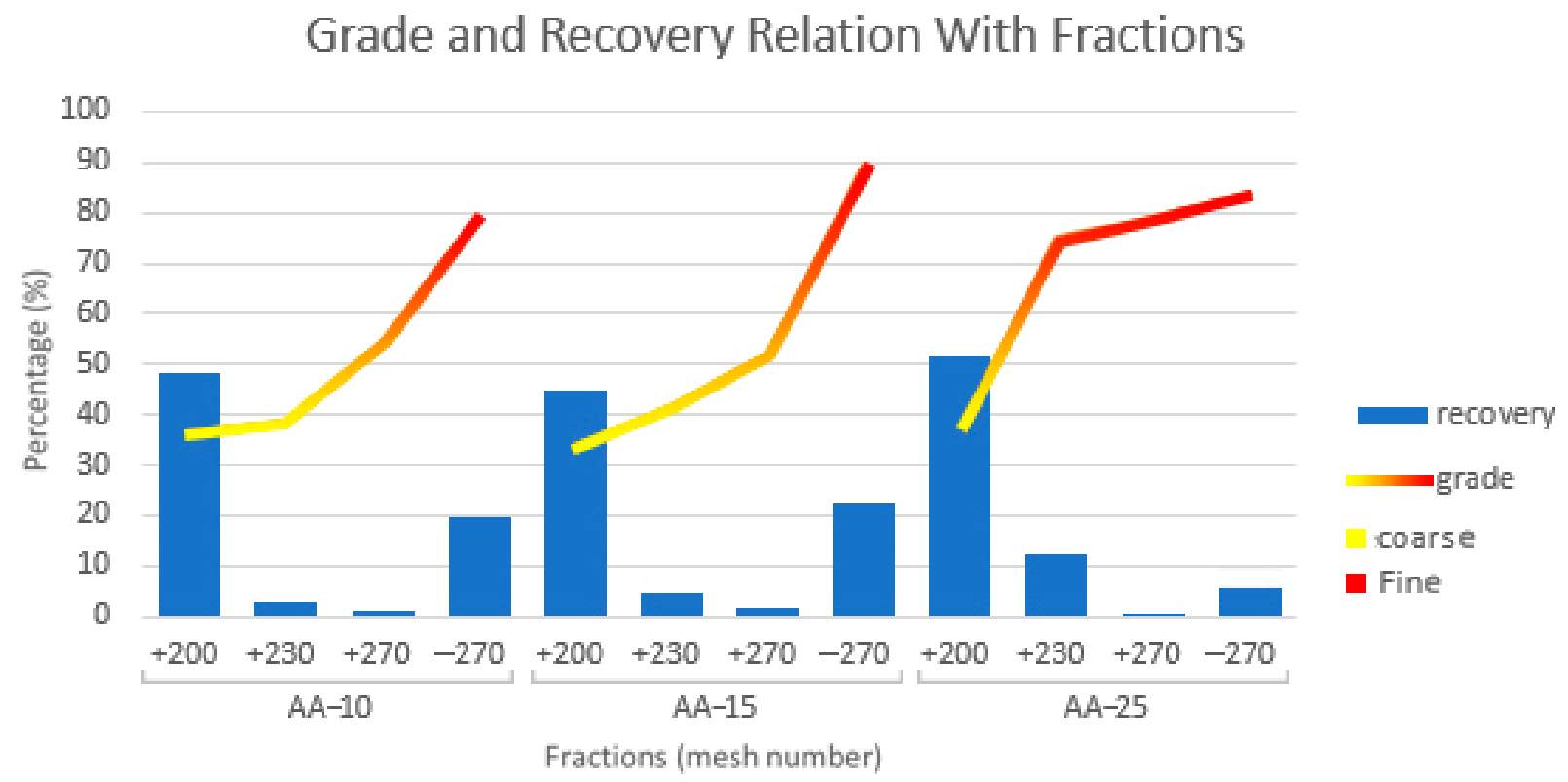

Figure 6. Graph representing 10, 15, and 25 min grinding times with their grades and recovery in $+200,+230$, and +270 fractions. The gradient color of the grade line represents the coarse fraction as yellow and the fine fraction as red, and blue bars represent the recovery.

Table 6. XRF results of -270 mesh size fraction after $15 \mathrm{~min}$ of grinding in the selective grinding unit.

\begin{tabular}{cc}
\hline Elements & Wt. Percentage \\
\hline $\mathrm{SiO}_{2}$ & 44.76 \\
$\mathrm{TiO}_{2}$ & 1.64 \\
$\mathrm{Al}_{2} \mathrm{O}_{3}$ & 33.49 \\
$\mathrm{Fe}_{2} \mathrm{O}_{3}$ & 1.07 \\
$\mathrm{MgO}$ & 0.42 \\
$\mathrm{CaO}$ & 0.19 \\
$\mathrm{Na}_{2} \mathrm{O}$ & 2.25 \\
$\mathrm{~K}_{2} \mathrm{O}$ & 0.19 \\
$\mathrm{P}_{2} \mathrm{O}_{5}$ & 0.14 \\
$\mathrm{LOI}$ & 15.84 \\
\hline
\end{tabular}

\subsection{Screening}

Screens of 60 and 400 mesh were chosen as the effective size range for the air classifier. The -400 -mesh fraction was not processed any further because it achieved a grade of $90.6 \%$ kaolinite and therefore was taken as a product on its own. It had a recovery of $20.5 \%$, which is relatively low. The +60 mesh fraction was reground to fall within the optimum size range of the air classifier. The $-60+400$ mesh, which had a kaolinite grade of $67.3 \%$, was fed into the air classifier. 


\section{Particle Size Distribution}

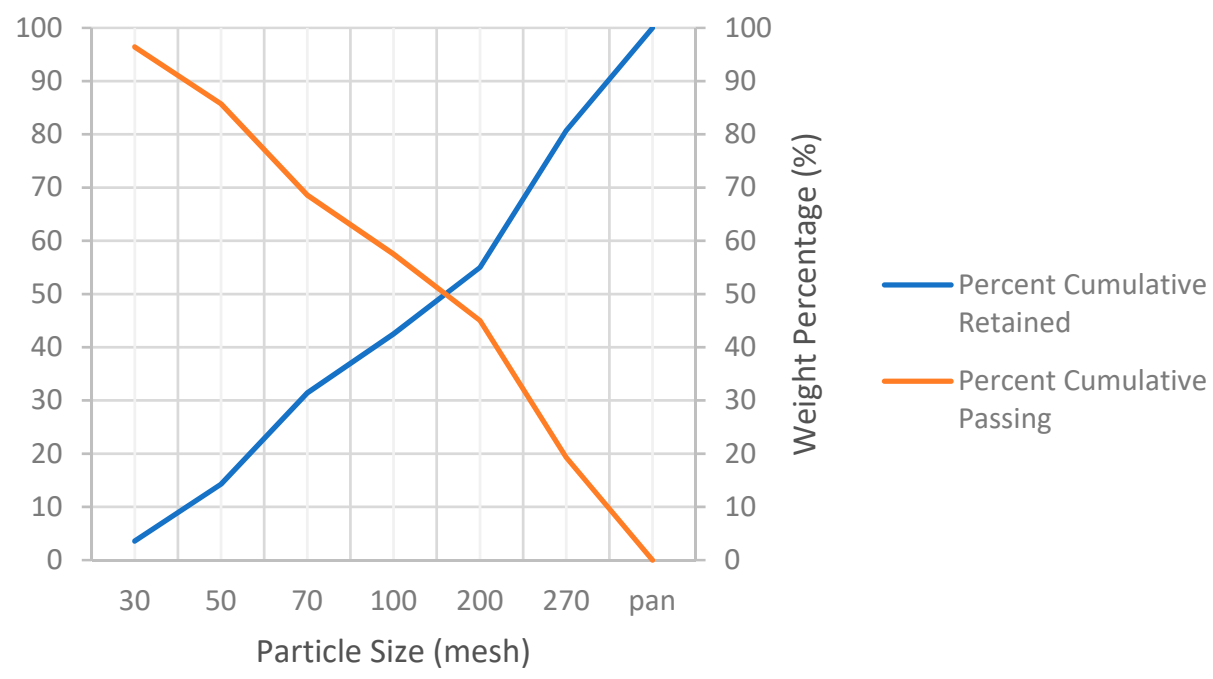

Figure 7. Granulometric analysis of kaolin after $15 \mathrm{~min}$ of grinding in the selective grinding unit. A P80 of 56 microns was observed.

\subsection{Air Classifier}

Central composite design was used to design the air classifier experiments as this approach can efficiently estimate first- and second-order terms. It can also model a response variable with curvature by adding center and axial points [43].

Figure 8 shows the grade and recovery for each of the designed experiments (Table 3 ). RunOrder 12 (Table 3) had the maximum recovery among all of the experimental runs, which was $28 \%$ with a grade of $90.2 \%$. This is because when the shutter was at the 2.5 position, it reduced the quantity of stream included in the concentrate (finer fraction), as shown in Figure 9. Recovery does not depend only on shutter opening but also on the speed of fan. The fan was only blowing particles towards the concentrate fraction. At a fan speed of $400 \mathrm{rpm}$, the kaolinite particles had relatively less drag force against their weight. The kaolinite particles stayed in the tailing fraction and the recovery of kaolinite in the concentrate was low. When the fan speed was increased, the drag force of air acting on the kaolinite particles was large enough to move these particles to the concentrate. As the speed was increased, a point was reached at which larger-sized impurities also started moving with the air because of increased drag force, and these impurities were reported in the concentrate. For instance, it was seen in RunOrder 7 and 12, for which the shutter opening was constant (2.5), that increasing the fan speed from 800 to $1366 \mathrm{rpm}$ decreased the recovery from $22.6 \%$ to $18.9 \%$.

\section{Grade and Recovery of Air Classifier Concentrates}

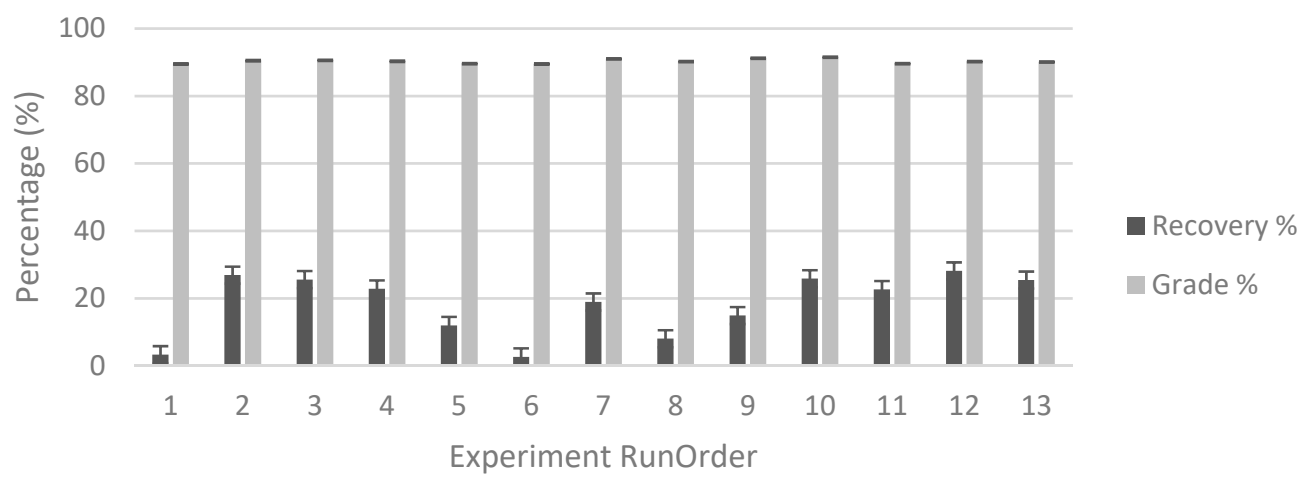

Figure 8. Grade and recovery percentage for the experiments of the air classifier listed in Table 3. 


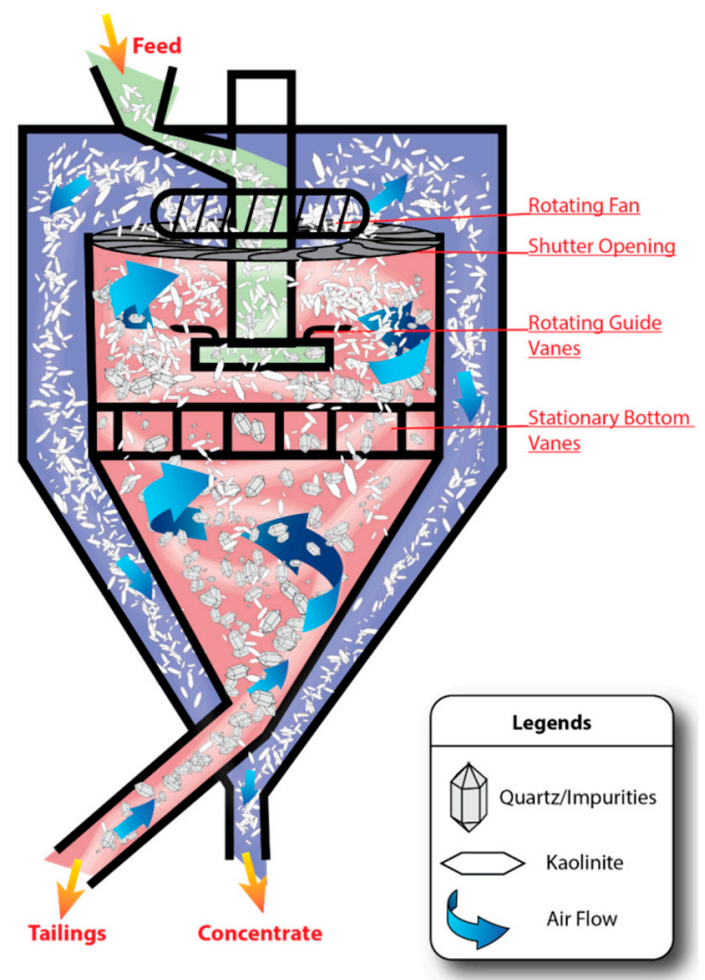

Figure 9. Air classifier's working schematics with shutter opening at 2.5.

During the air classifier experiments, it was observed that the shutter opening had no effect on grade. Furthermore, the speed of the fan also had a low impact on the grade. This could be explained due to the kaolinite stream size. The kaolinite stream is relatively large, and altering the grade should thus result in impurities in the stream. Even if the shutter is completely opened, it still cannot allow the stream of impurities to enter into the concentrate fraction. Increasing the speed of the fan increased the grade but the increment was not significant. For instance, the experiments of RunOrder 5 and 10 had the same shutter opening (4.0) but increasing the speed of fan from 400 to $1200 \mathrm{rpm}$ increased the grade from $89.6 \%$ to only $91.5 \%$. Overall, an increase of $31.9 \%$ in the grade of kaolinite was achieved during this study (Figure 10).

\section{Comparison of Feed with the Highest Grade Air Classfier Experiment}

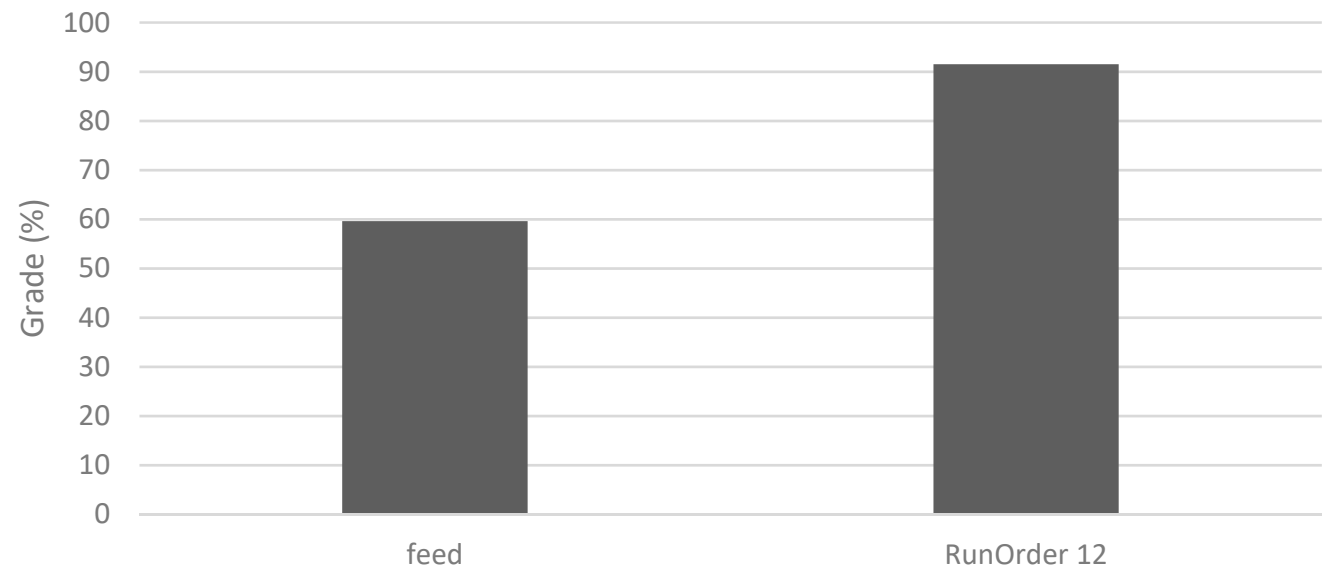

Figure 10. Comparison of the grade of feed and the highest grade achieved using the air classifier during RunOrder 12. 
The experimental data indicated the best conditions for the air classifier to function. To understand the combined effect of the parameters of the air classifier on the grade and recovery of kaolinite, and to develop mathematical models for sustainable dry beneficiation, statistical analysis of the experimental results was conducted.

\subsection{Statistical Analysis}

The response surface design was chosen for statistical analysis because of its feasibility with the type of variables and the focus of the study. To determine the most appropriate design for experimental analysis, the response surface was required to fit in the most efficient manner [44]. A stepwise procedure was used because of its improvement in prediction parameters [45]. Statistical design yielded empirical mathematical models based on experiments for predicting the grade and recovery. These are discussed below.

\subsubsection{Recovery Model}

Central composite design yielded a statistical model for the recovery of kaolinite as given by Equation (1).

$$
\text { Recovery } \%=-37.53+0.08675 \times \mathrm{A}+14.66 \times \mathrm{B}-0.000045 \times(\mathrm{A})^{2}-2.251 \times(\mathrm{B})^{2}
$$

where $\mathrm{A}$ is the speed of the fan (rpm) and B is the shutter opening.

A smaller $p$-value corresponds to a more significant result. For the full quadratic model of recovery, the large $p$-value for the lack of fit was 0.916 , suggesting that this model adequately fits the data. The small $p$-values for the squared terms $(p=0.00)$ suggested that there is curvature in the response surface. Small $p$-values for fan speed squared $(p=0.00)$ and shutter opening squared $(p=0.00)$ indicate that these variables have a statistically significant effect on recovery. The values for $S$ (standard error), coefficient of determination $\left(\mathrm{R}^{2}\right)$, adjusted $\mathrm{R}^{2}$, and predicted $\mathrm{R}^{2}$ were determined for the statistical model of recovery. The value of $S=1.6$, was, close to zero. Predicted $R^{2}$ for the model of recovery was $96 \%$, which was indicative of promising predictive abilities for the new observations. With this statistical model, the combined effect of air classifier parameters on recovery can be observed by the contour plot.

The contour plot of recovery between shutter opening and speed of fan is shown in Figure 11. It shows that the area of highest recovery ranges from 600 to $1300 \mathrm{rpm}$ of fan speed. At speeds less than $600 \mathrm{rpm}$, the force of air is too weak to carry the particles to the concentrate. However, kaolinite particles, which are smaller in size due to differential grinding, start moving to the concentrate fraction as the speed increases. As the speed of the fan increases beyond $1300 \mathrm{rpm}$, it might cause turbulence which enables the coarser particles of impurities to move towards the concentrate fraction. At shutter opening above 1.5 , the recovery was greater than $20 \%$ (Figure 11). This is because a shutter opening of 1.5 allowed more particles of kaolinite to mix with the finer fraction (Figure 9).

The quadratic mathematical model of recovery as depicted in Equation (1) predicted the highest recovery of $28.3 \%$ at a fan speed of $965 \mathrm{rpm}$ and shutter opening of 3.25 (Figure 12).

\subsubsection{Grade Model}

The model for Grade \% developed by central composite design based on the responses is given by Equation (2). This model suggests that shutter opening has no effect on grade, and the speed of the fan has a very low impact on grade.

$$
\text { Grade } \%=88.862+0.001788 \times \mathrm{A}
$$

where $\mathrm{A}$ is speed of fan (rpm).

The statistical model of the grade yielded the variance inflation factor (VIF) value, which was not greater than 5 . This shows that the regression coefficients were estimated correctly. The term $S=0.32$ was small and close to zero. Predicted $\mathrm{R}^{2}$ for the model of 
grade was $70.20 \%$, which is indicative of promising predictive abilities. The model in Equation (2) suggests that the highest grade, of $91.4 \%$, can be achieved at a fan speed of 1366 rpm (Figure 13).

\section{Contour Plot of Recovery (\%) vs Shutter Opening, Speed of Fan (rpm)}
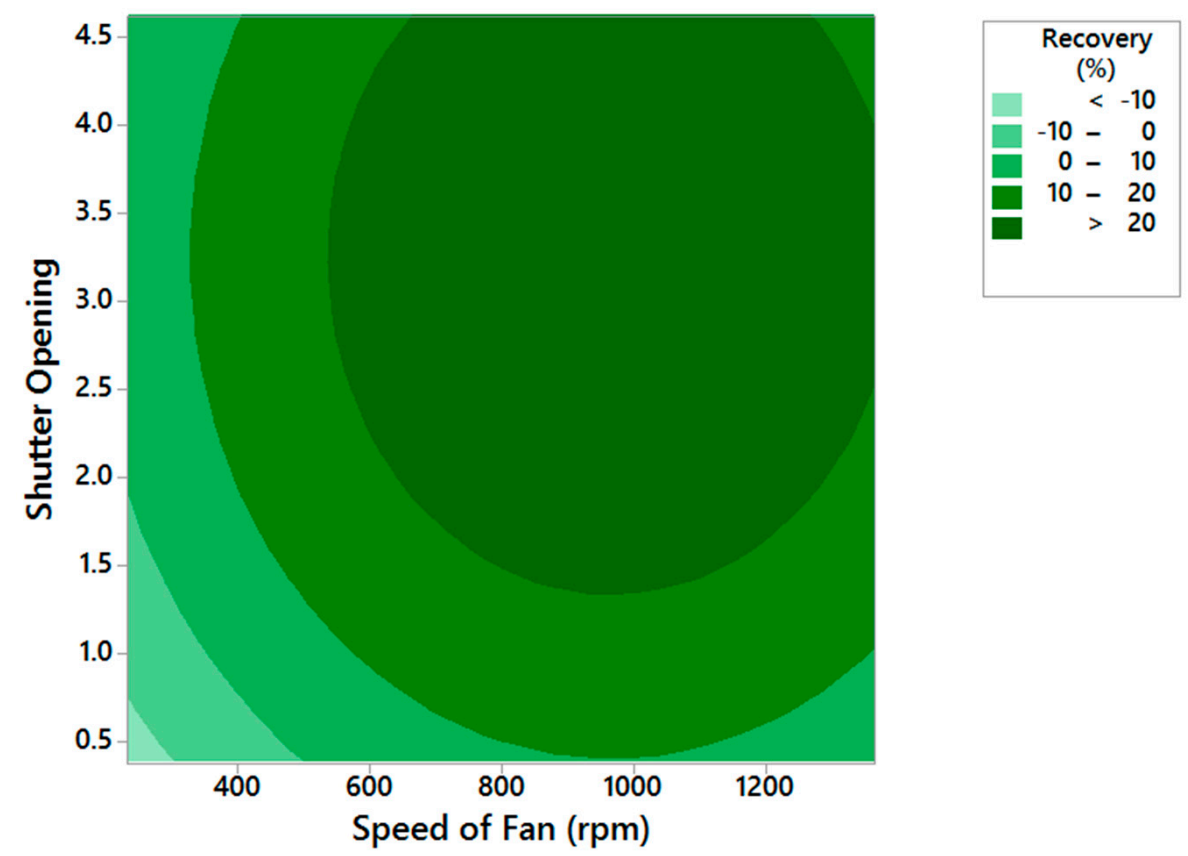

Figure 11. Contour plot of recovery (\%) showing shutter opening vs. speed of fan (rpm).

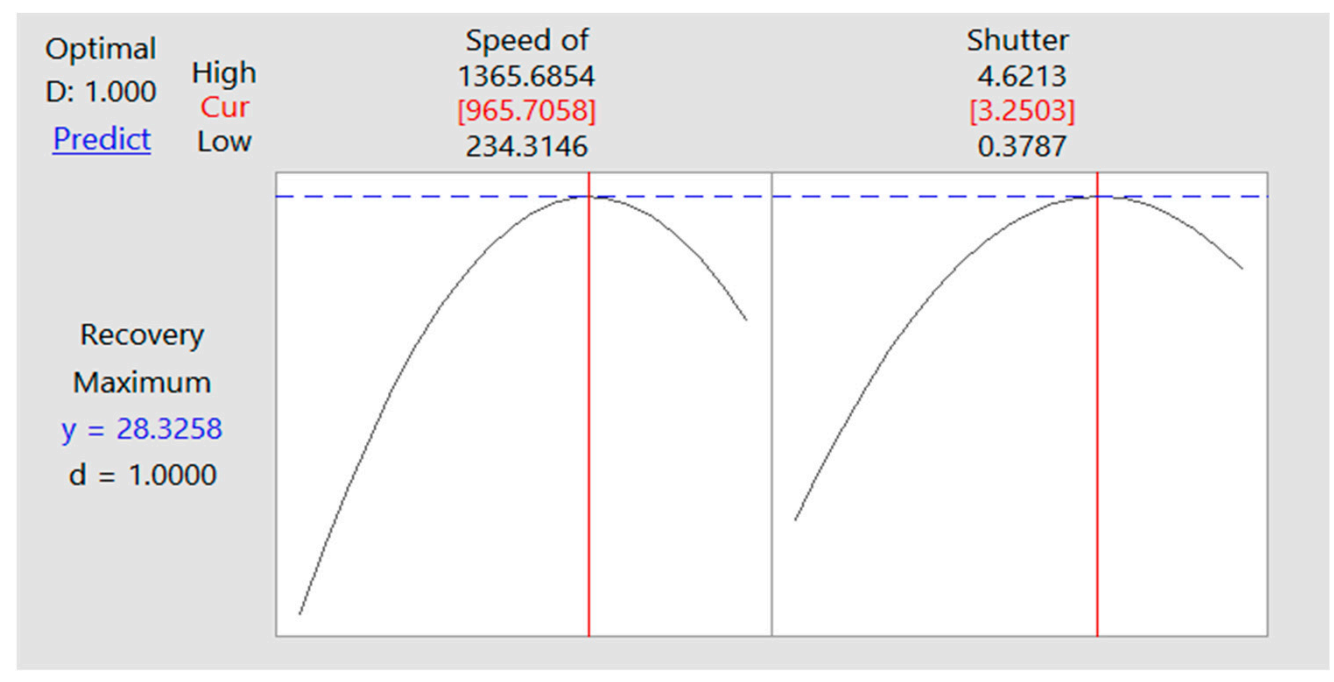

Figure 12. Optimized plot for the highest recovery in the air classifier's product.

\subsubsection{Optimal Conditions}

The solution shown in Figure 14 is based on the maximization of both grade and recovery by combining the models in Equations (1) and (2). It was noted that at shutter opening of 3.2 and speed of fan of $1251 \mathrm{rpm}$, the grade and recovery models predicted the highest values of grade and recovery to be $91.1 \%$ and $24.7 \%$, respectively. This prediction has composite desirability (0.83) close to 1 , which indicates the settings appear to achieve favorable results for all responses as a whole. These predictions were only statistical guesses based on the results obtained by the experimentation; thus, validation was required. 


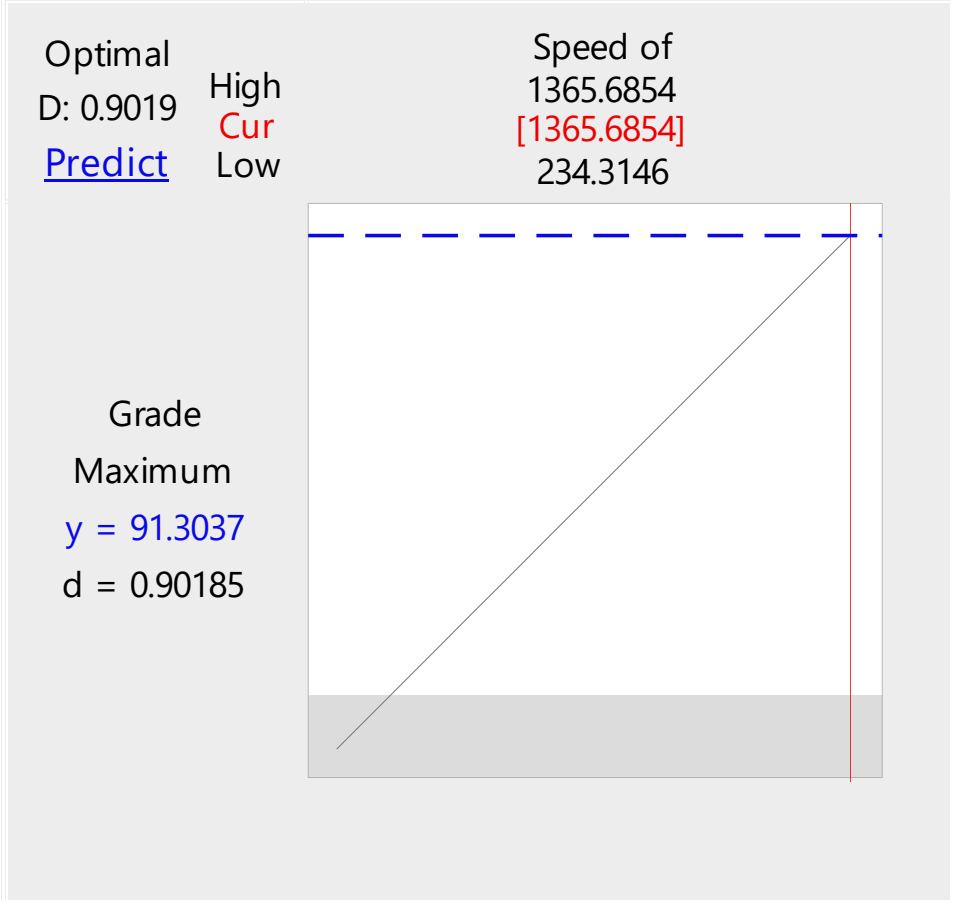

Figure 13. Optimized plot for the highest grade in the air classifier's product.

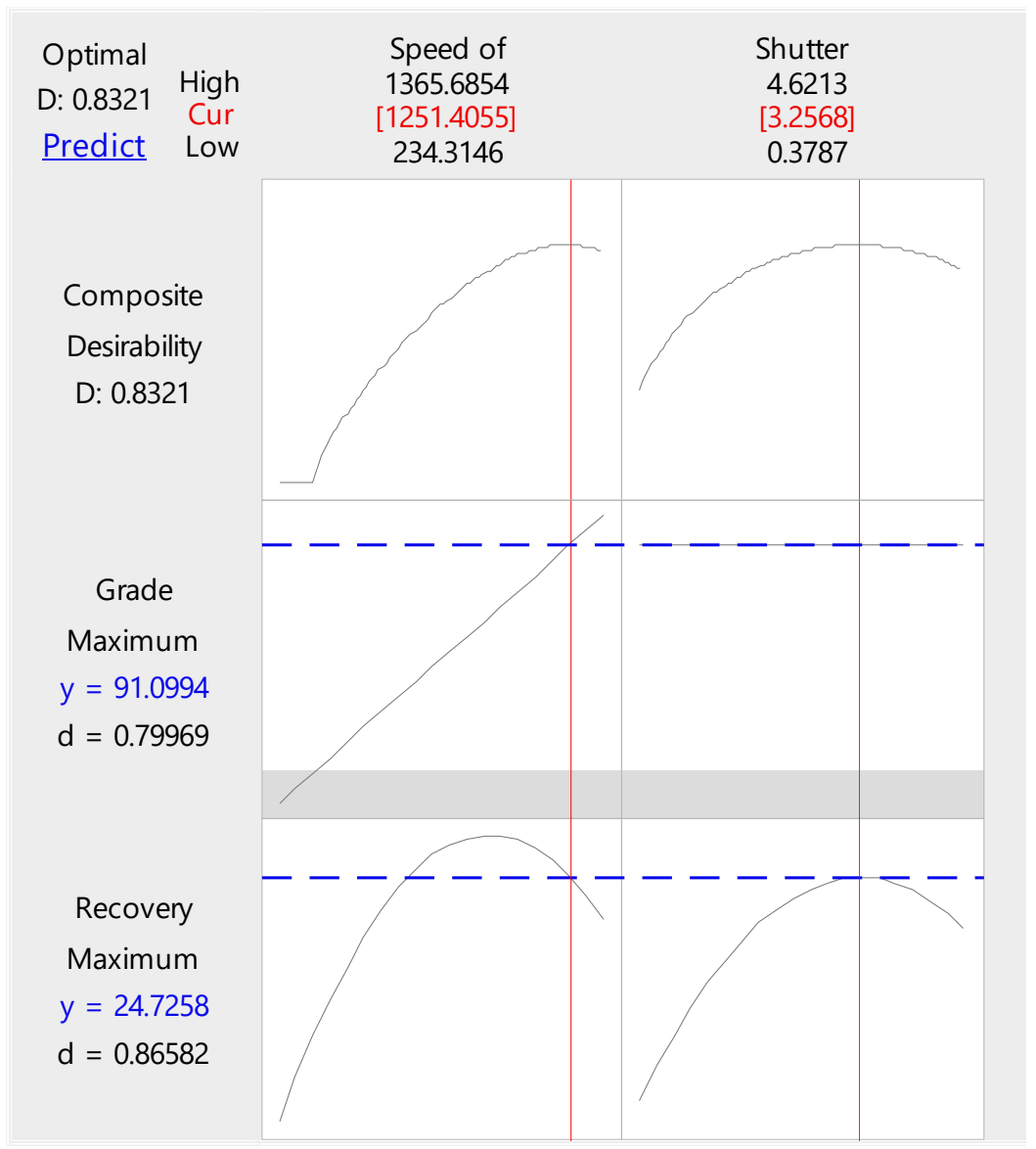

Figure 14. Optimized plot for the highest predicted grade and recovery in the air classifier's product. 


\subsubsection{Validation}

To validate the accuracy of these predictions, an experimental set was carried out as per the optimal operating conditions shown in Figure 14. The XRD test result of the concentrate obtained as a result of these operating conditions is shown in Figure 15. It was observed that the difference in grade between predicted and actual values was only about $0.1 \%$ and in recovery was only $2.36 \%$.

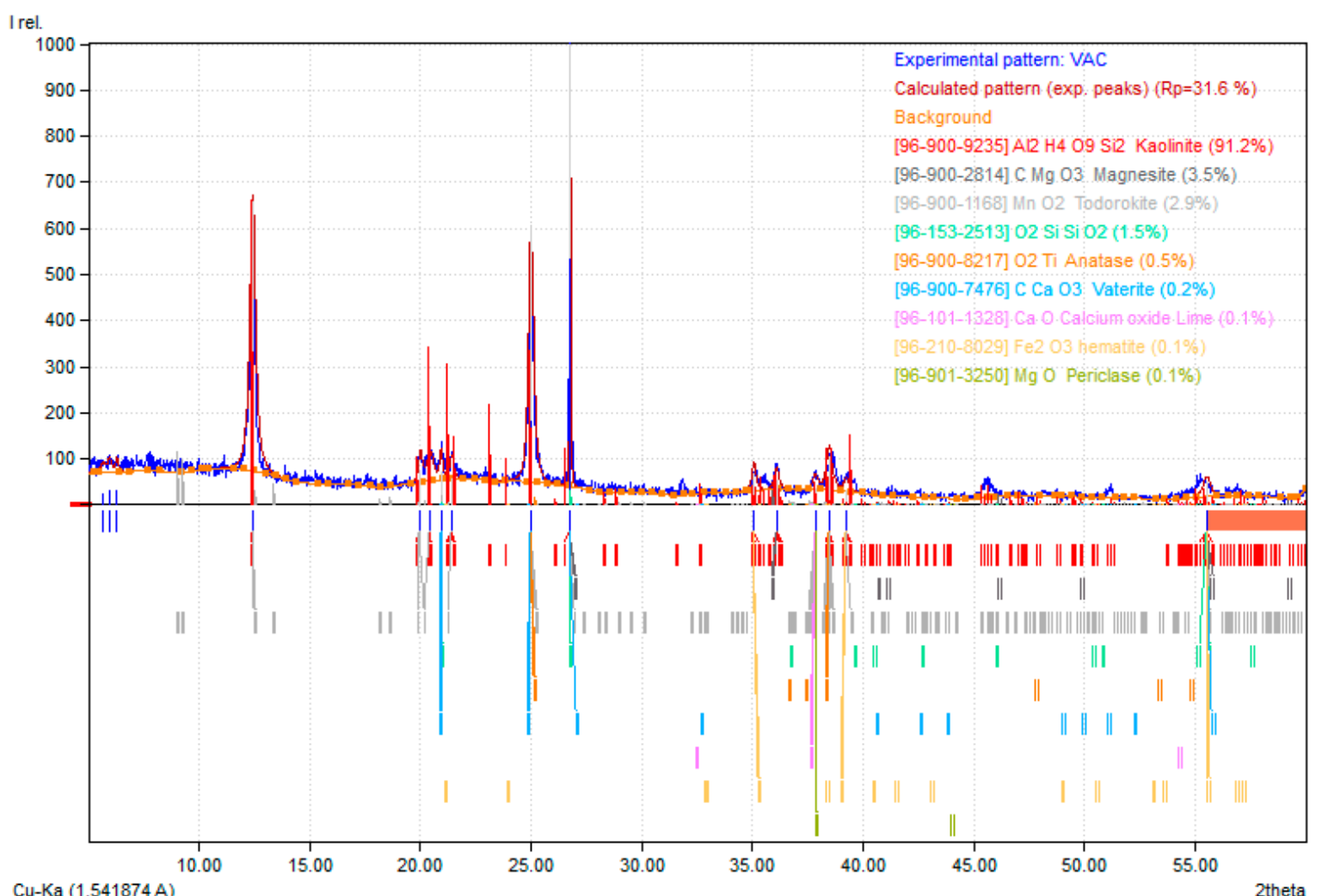

Figure 15. The XRD pattern of kaolin concentrate after the air classifier in the validation test.

This study was limited in scope for the removal of impurities such as quartz, iron, and titanium using an air classifier and screening. A magnetic separator placed ahead of the air classifier may help in further reducing the impurities.

\section{Conclusions}

The purpose of this study was to contribute towards the limited literature available on dry processing of kaolin. This study is thus highly significant because processing using less water is important for the sustainable future of the mineral processing industry. For this purpose, kaolin samples were collected from Nagar Parkar, in the Sindh province of Pakistan. Dry processing of kaolin was carried out through crushing, selective grinding, screening, and air classification.

The summary of results shown in Table 7 demonstrates the quantitative change from the feed to the screening product (Product 1) and the air classifier product (Product 2) using the flowsheet designed in this study. Kaolin was upgraded from $59.6 \%$ to $91.2 \%$ by the designed dry process.

It is important to note that the air classifier product achieved the highest grade of $91.2 \%$ and the highest recovery of $27.1 \%$. The quartz impurities in the screening product are relatively lower, by $1.4 \%$, compared to those of the air classifier product. In the screening product, the percentage of $\mathrm{Fe}_{2} \mathrm{O}_{3}$ is $2.2 \%$ greater than the iron content in the air classifier product. 
Table 7. Comparison of the constituents of kaolin feed with the products of this study (Product 1 (through screening) and Product 2 (through air classifier)).

\begin{tabular}{cccc}
\hline Constituent & Feed & Product 1 (-400 Mesh) & Product 2 (Conc. of Air Classifier) \\
\hline $\mathrm{Kaolinite}$ & $59.6 \%$ & $90.6 \%$ & $91.2 \%$ \\
$\mathrm{SiO}_{2}$ & $12.0 \%$ & $0.1 \%$ & $1.5 \%$ \\
$\mathrm{TiO}_{2}$ & $1.2 \%$ & $1.1 \%$ & $0.5 \%$ \\
$\mathrm{Fe}_{2} \mathrm{O}_{3}$ & $4.8 \%$ & $2.3 \%$ & $0.1 \%$ \\
$\mathrm{MgCO}_{3}$ & $4.8 \%$ & $3.0 \%$ & $3.5 \%$ \\
$\mathrm{CaCO}_{3}$ & $8.3 \%$ & $0.4 \%$ & $0.2 \%$ \\
$\mathrm{CaO}$ & $0.8 \%$ & $0.1 \%$ & $0.1 \%$ \\
$\mathrm{MgO}$ & $3.4 \%$ & $0.0 \%$ & $0.1 \%$ \\
$\mathrm{MnO}_{2}$ & $5.1 \%$ & $2.4 \%$ & $2.9 \%$ \\
\hline
\end{tabular}

The general conclusions drawn from this project are presented below:

- Selective grinding worked effectively for kaolinite of hardness 2.5 and quartz of hardness 7.0.

- Undersize screening (-400 mesh) was taken as the product and achieved a grade and recovery of $90.6 \%$ and $20.5 \%$, respectively.

- The highest grade of $91.5 \%$ with recovery of $25.8 \%$ was achieved in the air classifier experiment at a fan speed of $1200 \mathrm{rpm}$ and shutter opening of 4.0 .

- The statistical model based on air classifier experiments for grade optimized the speed of the fan to be $1366 \mathrm{rpm}$. The model predicts that the maximum grade will be $91 \%$. The grade was found to only depend upon the speed of fan.

- The statistical model based on air classifier experiments for recovery optimized the speed of the fan at $966 \mathrm{rpm}$. The shutter opening's optimized value was 3.2. With these input variables, the model predicts that the maximum recovery of $28.4 \%$ will be achieved.

- To optimize both grade and recovery of the air classifier, the models predicted that the fan speed and shutter opening should be $1251 \mathrm{rpm}$ and 3.0, respectively. At these values, the predicted recovery was found to be $24.7 \%$ and grade to be $91.1 \%$.

This designed methodology has the potential to eliminate quartz impurities and can also decrease the quantity of color-imparting impurities, such as $\mathrm{Fe}_{2} \mathrm{O}_{3}$ and $\mathrm{TiO}_{2}$, without using any water. It can replace the wet methods and can save millions of tons of fresh water. Furthermore, it can be the baseline for the sustainable future of processing and extraction industries.

To optimize the process it is necessary to further examine the dynamics of the separation system using air classifiers and grinding materials (balls). It would be of interest to use an air classifier with a wider feed range, which could save the cost of regrinding the +60 mesh fraction. It may also be worthwhile to develop a hybrid process by including a bleaching method at the end of dry processing. This bleaching step will greatly increase the brightness of kaolin, thus increasing its value.

Author Contributions: Conceptualization of this study was done by M.B.H., M.D. and A.H.; methodology was carried out by M.D. and A.H.; Minitab and XRD software by M.D. and A.H.; validation was done by M.D., A.H., M.B.H. and M.M.Z.; resources were gathered by M.B.H. and M.M.Z.; writing—original draft preparation was done by M.D., M.B.H., A.H.; writing—review and editing was done by M.Z.E. and M.M.Z.; supervision was done by M.B.H., M.M.Z. and M.Z.E.; project administration includes M.B.H., M.Z.E. and M.M.Z.; funding acquisition was done by M.B.H. and M.M.Z. All authors have read and agreed to the published version of the manuscript.

Funding: This work was funded by University of Engineering and Technology, Lahore, Pakistan Contingencies (Sub-Head of "Final Year Project", Code No. 22003).

Institutional Review Board Statement: Not applicable.

Informed Consent Statement: Not applicable. 


\section{Data Availability Statement: Not applicable.}

Acknowledgments: We are thankful to Ahmad Saeed and Company (Pvt.) Limited Pakistan for providing full technical support and sample acquisition.

Conflicts of Interest: The authors declare no conflict of interest.

\section{References}

1. Schroeder, P.A. Kaolin. New Georgia Encyclopedia. 2018. Available online: https://www.georgiaencyclopedia.org/articles/ business-economy/kaolin (accessed on 11 January 2019).

2. Pohl, W.L. Economic Geology: Principles and Practice; Wiley-Blackwell: Chichester, UK, 2011; ISBN 978-1-4443-3662-7.

3. Larroyd, F.; Petter, C.O.; Sampaio, C.H. Purification of north Brazilian kaolin by selective flocculation. Miner. Eng. 2002, 15, 1191-1192. [CrossRef]

4. Agrawal, P.; Misra, S.N.; Sharma, T. Beneficiation of Low Grade Kaolin by High Shear Agitation with Dispersant (HSD) Pre-Treatment for High Yield and Improved Fired Colour. Trans. Indian Ceram. Soc. 2014, 73, 48-57. [CrossRef]

5. Murray, H.H. Major kaolin processing developments. Int. J. Miner. Process. 1980, 7, 263-274. [CrossRef]

6. Avadiar, L.; Leong, Y.-K.; Fourie, A. Sedimentation of Kaolin: Effects of Polyethylenimine (Pei) Flocculants and Application of Shear. In Proceedings of the Chemeca 2012: Quality of Life through Chemical Engineering, Wellington, New Zealand, 23-26 September 2012; Engineers Australia: Barton, KS, USA, 2012.

7. Iannicelli, J.; Pechin, J.; Ueyama, M.; Ohkura, K.; Hayashi, K.; Sato, K.; Lauder, A.; Rey, C. Magnetic Separation of Kaolin Clay Using a High Temperature Superconducting Magnet System. In IEEE Transactions on Applied Superconductivity; IEEE: Piscataway, NJ, USA, 1997; Volume 7.

8. Abdel-Khalek, N.A.; Selim, K.A.; Yassin, K.E.; Hamdy, A.; Heikal, M.A. Upgrading of low grade egyptian kaolin ore using magnetic separation. J. Basic Environ. Sci. 2017, 4, 247-252.

9. Luz, A.B.; Middea, A. Purification of kaolin by selective flocculation. In Proceedings of the 43rd Annual Conference of Metallurgist of CIM, Hamilton, ON, Canada, 22-25 August 2004; pp. 243-253.

10. Kumar, G.; Menon, S.K.; Agrawal, Y.K.; Vora, S.B. Selective flocculation separation of iron and titanium from Kutch kaolins. Indian J. Eng. Mater. Sci. 2001, 8, 170-176. (In Indian)

11. Yoon, R.-H.; Nagaraj, D.R.; Wang, S.S.; Hildebrand, T.M. Benefication of kaolin clay by froth flotation using hydroxamate collectors. Miner. Eng. 1992, 5, 457-467. [CrossRef]

12. Luz, A.; Yildirim, I.; Yoon, R.-H. Purification of Brazilian Kaolin Clay by Flotation. Dev. Miner. Process. 2000, 13, C8b-79-C8b-83.

13. Hosseini, M.R.; Ahmadi, A. Biological Beneficiation of Kaolin: A Review on Iron Removal. Appl. Clay Sci. 2015, 107, 238-245. [CrossRef]

14. de Mesquita, L.M.S.; Rodrigues, T.; Gomes, S.S. Bleaching of Brazilian kaolins using organic acids and fermented medium. Miner. Eng. 1996, 9, 965-971. [CrossRef]

15. Zegeye, A.; Yahaya, S.; Fialips, C.I.; White, M.L.; Gray, N.D.; Manning, D.A.C. Refinement of industrial kaolin by microbial removal of iron-bearing impurities. Appl. Clay Sci. 2013, 86, 47-53. [CrossRef]

16. Maurya, C.B.; Dixit, S.G. Effect of pH on the high-gradient magnetic separation of kaolin clays. Int. J. Miner. Process. 1990, 28, 199-207. [CrossRef]

17. Guo, M.; Lin, Y.; Xu, X.; Chen, Z. Bioleaching of iron from kaolin using Fe(III)-reducing bacteria with various carbon nitrogen sources. Appl. Clay Sci. 2010, 48, 379-383. [CrossRef]

18. Cameselle, C.; Ricart, M.T.; Núñez, M.J.; Lema, J.M. Iron removal from kaolin. Comparison between "in situ" and "two-stage" bioleaching processes. Hydrometallurgy 2003, 68, 97-105. [CrossRef]

19. Prasad, M.S.; Reid, K.J.; Murray, H.H. Kaolin: Processing, properties and applications. Appl. Clay Sci. 1991, 6, 87-119. [CrossRef]

20. Jankovic, A.; Suthers, S.; Wills, T.; Valery, W. Evaluation of dry grinding using HPGR in closed circuit with an air classifier. Miner. Eng. 2015, 71, 133-138. [CrossRef]

21. Altun, O.; Benzer, H.; Dundar, H.; Aydogan, N.A. Comparison of open and closed circuit HPGR application on dry grinding circuit performance. Miner. Eng. 2011, 24, 267-275. [CrossRef]

22. Kogel, J.E. Mining and processing kaolin. Elements 2014, 10, 189-193. [CrossRef]

23. Northey, S.A.; Mudd, G.M.; Saarivuori, E.; Wessman-Jääskeläinen, H.; Haque, N. Water footprinting and mining: Where are the limitations and opportunities? J. Clean. Prod. 2016, 135, 1098-1116. [CrossRef]

24. Peng, Y.; Li, Y.; Li, W.; Fang, X.; Liu, C.; Fan, R. Elimination of adverse effects of seawater on molybdenite flotation using sodium silicate. Miner. Eng. 2020, 146, 106108. [CrossRef]

25. Reyes, C.; Álvarez, M.; Ihle, C.F.; Contreras, M.; Kracht, W. The influence of seawater on magnetite tailing rheology. Miner. Eng. 2019, 131, 363-369. [CrossRef]

26. Jeldres, R.I.; Arancibia-Bravo, M.P.; Reyes, A.; Aguirre, C.E.; Cortes, L.; Cisternas, L.A. The impact of seawater with calcium and magnesium removal for the flotation of copper-molybdenum sulphide ores. Miner. Eng. 2017, 109, 10-13. [CrossRef]

27. Aitimbetov, T.; White, D.M.; Seth, I. Biological gold recovery from gold-cyanide solutions. Int. J. Miner. Process. 2005, 76, 33-42. [CrossRef] 
28. Rubio, J.; Souza, M.L.; Smith, R.W. Overview of flotation as a wastewater treatment technique. Miner. Eng. 2002, 15, 139-155. [CrossRef]

29. Gregory, S. Top 12 Kaolin Exporting Countries-WorldAtlas.com. Economics. 2017. Available online: https://www.worldatlas. com/articles/top-12-kaolin-exporting-countries.html (accessed on 2 December 2018).

30. Muslim, M.; Akhtar, T.; Khan, Z.M.; Khan, T. Geology of Nagar Parkar area, Thar Parkar district, Sindh, Pakistan. Geol. Surv. Pak. Inf. Release 1997, 605, 1-21.

31. Ismail, S.; Husain, V.; Hamid, G.; Bilal, M. Physico-chemical characteristics of Nagar Parkar kaolin deposits, Thar Parkar district, Sindh, Pakistan. J. Himal. Earth Sci. 2015, 48, 50-58.

32. Holmes, C.G. Grinding Method and Apparatus. Google Patents US1807383A, 26 May 1931. Available online: https:/ /patents google.com/patent/US1807383 (accessed on 1 December 2019).

33. Baláž, P.; Achimovičová, M.; Sanchez, M.; Kammel, R. Attrition Grinding and Leaching of Enargite Concentrate. Metall 1999, 53, 53-56.

34. Piga, L.; Marruzzo, G. Preconcentration of an Italian talc by magnetic separation and attrition. Int. J. Miner. Process. 1992, 35, 291-297. [CrossRef]

35. Feng, Y.; Liu, J.; Liu, S. Effects of operating parameters on flow field in a turbo air classifier. Miner. Eng. 2008, 21, 598-604. [CrossRef]

36. Eswaraiah, C.; Angadi, S.I.; Mishra, B.K. Mechanism of particle separation and analysis of fish-hook phenomenon in a circulating air classifier. Powder Technol. 2012, 218, 57-63. [CrossRef]

37. Everett, J.; Jeffrey Peirce, J. Effect of feed rate and classifier height on air classification. J. Environ. Eng. 1990, 116, 735-745. [CrossRef]

38. Danishwar, M.; Hamid, A.; Hayat, M. Quadratic Mathematical Modeling of Sustainable Dry Beneficiation of Kaolin; University of Engineering and Technology: Lahore, Pakistan, 2019.

39. Davis, S.B.; Dawson, M.F. A laboratory study of attrition grinding. J. S. Afr. Inst. Min. Metall. 1989, 89, $231-241$.

40. Davis, E.G. Beneficiation of Olivine Foundry Sand by Differential Attrition Grinding. U.S. Patent US4039625A, 2 August 1977.

41. Murray, H.H.; Alves, C.A.; Bastos, C.H. Mining, processing and applications of the Capim Basin kaolin, Brazil. Clay Miner. 2007, 42, 145-151. [CrossRef]

42. Mukherjee, S. Applied Mineralogy: Applications in Industry and Environment; Springer Science \& Business Media, Capital Publishing Company: New Dehli, India, 2012; ISBN 940071162X.

43. Ahmadi, M.; Vahabzadeh, F.; Bonakdarpour, B.; Mofarrah, E.; Mehranian, M. Application of the central composite design and response surface methodology to the advanced treatment of olive oil processing wastewater using Fenton's peroxidation. J. Hazard. Mater. 2005, 123, 187-195. [CrossRef]

44. Box, G.E.P.; Draper, N.R. A Basis for the Selection of a Response Surface Design. J. Am. Stat. Assoc. 1959, 54, 622-654. [CrossRef]

45. Peduzzi, P.N.; Hardy, R.J.; Holford, T.R. A stepwise variable selection procedure for nonlinear regression models. Biometrics 1980, 36, 511-516. [CrossRef] [PubMed] 